Marquette University

e-Publications@Marquette

English Faculty Research and Publications

English, Department of

$1-1-2016$

\title{
Tending to One’s Garden: Deschamps's 'Ballade to Chaucer' Reconsidered
}

Elizaveta Strakhov

Marquette University, yelizaveta.strakhov@marquette.edu

Published version. Medium Aevum, Vol. 85, No. 2 (2016): 236-258. Publisher link. (C) 2016 The Society for the Study of Medieval Languages and Literature. Used with permission. 


\section{TENDING TO ONE'S GARDEN: DESCHAMPS'S 'BALLADE TO CHAUCER' RECONSIDERED}

Sometime towards the end of the fourteenth century, the French poet Eustache Deschamps wrote a formes fixes ballade addressed to Geoffrey Chaucer. Somewhat surprisingly, this address appears to be the only known direct acknowledgement of Chaucer's literary activity to have been made within the English poet's own lifetime, and it is famously ambiguous. In the lyric, Deschamps compares Chaucer to multiple venerable figures, such as Socrates, Seneca, and Ovid, as one who has illuminated England. He further commends Chaucer for having translated that Ur-text of French courtly love literature, the Roman de la Rose, 'en bon anglès' (line i6: 'into good English') and for planting a literary garden in England that will be full of French plants. ${ }^{1}$ While Deschamps remains far from the fountain of Helicon in France, Chaucer has the fountain under his 'baillie' (line 23: 'jurisdiction'). That all said, Deschamps declares that he is sending work to Chaucer but does not ask for any of Chaucer's in return, and he famously refers to him in the refrain as 'grant translateur, noble Geoffroi Chaucier'.

Where earlier critics had scarcely doubted the sincerity of Deschamps's high valuation of Chaucer, William Calin tempered the enthusiasm by questioning how much this ballade could really be saying about Chaucer's fame on the Continent and Deschamps's interest in English literature. ${ }^{2}$ Many of Deschamps's other lyrics testify to his strongly anti-English and proto-nationalistic sentiments, such as the ballades in which he paints idealizing futures that see England wiped from the very face of the earth. ${ }^{3}$ There is also no evidence that Deschamps, in fact, knows more than a few words of English, as observable from his well-known ballade on an encounter with two menacing English soldiers in Calais, in which he mocks their alien-sounding language. ${ }^{4}$ The insistent refrain within the lyric - 'grant translateur, noble Geffroy Chaucier' - has the ring of praise to it, but it is also potentially dismissive, or, at the very least, vexed. Ardis Butterfield too reads all of Deschamps's compliments to Chaucer as subtly backhanded. Thus Deschamps's portrayal of the fountain of Helicon as being in Chaucer's 'baillie' recalls for her, in its legalistic use of the term, the English siege and subsequent occupation of Calais in 1346 and the destructive pillaging of its surrounding region by the troops of the Black Prince in the decades to come. ${ }^{5}$ For John Bowers, 
the whole ballade is an 'exercise in hyperbole' and a 'subtle effort in demeaning Chaucer's enterprise as the mere importation of the French Rose for an English garden'. ${ }^{6}$ The ballade generally tends to be read in the context of Deschamps's anti-English political sentiments. Indeed, scholars seeking to date the ballade have favoured periods of peace or of less strained political conditions between England and France as the most suitable possibilities. ${ }^{7}$

As this piece argues, however, Deschamps's 'Ballade to Chaucer' is about far more than Deschamps's degree of familiarity with Chaucer's work. Rather, this ballade sheds light on a significant feature of late medieval Anglo-French translation practice that has heretofore received comparatively less attention. Scholarly discussions of Anglo-French literary exchange have tended to focus on issues surrounding language, linguistic difference being clearly a fundamental feature of translation activity. ${ }^{8}$ Yet, as I aim to show, Anglo-French literary exchange was also heavily concerned with policing the transmission of literary form and of literary tropes, with a special interest in the transmission of references to classical antiquity. While synchronic translation between contemporary languages and literatures was, necessarily, a dominant feature of Anglo-French literary exchange, the diachronic translation of antiquity became an important yardstick for evaluating a cross-Channel poet's literary achievements, particularly within the tense geopolitical climate created by the Hundred Years War.

In what follows, I demonstrate that the classical allusions in Deschamps's ballade to Chaucer point to three overlapping intertexts for the poem that together help explicate its ideological manœuvres. In the first place, Deschamps's particular selection of classical allusions echoes an earlier exchange of invectives between Philippe de Vitry, an early French humanist from outside of Paris, and Jean de le Mote, a native of French-speaking Hainault who resided in England at the court of Edward III. These invectives debate the ways in which antiquity should be translated over to England, given contemporary AngloFrench political tensions, and are crucial to understanding Deschamps's poem. Deschamps's classical allusions further echo a different ballade of his, in which Deschamps repeatedly emphasizes his own practice of diachronic translation from antiquity as a measure of his poetic success. The wealth of parallels between this work and the address to Chaucer suggests that, rather than diminish Chaucer's activities by calling him a translator, Deschamps equates Chaucer's achievements to his own lifelong literary accomplishments because they are both translators from classical antiquity. However, Deschamps's references to antiquity also invoke a third major literary intertext, Ovid's Epistulae ex Ponto IV. 2, thus bringing the image of the classical poet in exile to bear on these questions of wartime Anglo-French translation and exchange. By teasing out these intertexts, we discover that Deschamps's address to Chaucer is about far more than the question of Chaucer's fame outside England: it is, instead, a 
sophisticated exploration of what it means to be a 'grant translateur' in war-torn francophone Europe.

\section{Deschamps's 'Ballade to Chaucer' and its Vitry-Le Mote intertext}

\section{While Deschamps's address to Chaucer does register a sense of Chaucer's linguistic alterity with his reference to Chaucer's 'bon anglès', his ballade mainly focuses on comparisons between Chaucer and various figures from antiquity. Deschamps writes:}

O Socrates, plains de philosophie, Seneque en meurs et Auglux en pratique, Ovides grans en ta poeterie Bries en parler, saiges en rhetorique, Aigles treshaulz, qui par ta theorique Enlumines le regne d'Eneas,

L'Isle aux Geans, ceuls de Bruth, et qui as Semé les fleurs et planté le rosier, Aux ignorans de la langue prandras, Grant translateur, noble Geffroy Chaucier.

Tu es d'amours mondains diex en Albie, Et de la Rose, en la terre Angelique, Qui d'Angela saxonne et puis flourie Angleterre - d'elle ce nom s'applique, Le derrenier en l'ethimologique En bon anglès le livre translatas, Et un vergier ou du plant demandas

De ceuls qui font pour eulx actorisier, A ja longtemps que tu edifias, Grant translateur, noble Geffroy Chaucier.

A toy pour ce de la fontaine Helye Requier avoir un buvraige autentique, Dont la doys est du tout en ta baillie, Pour rafrener d'elle ma soif ethique; Qui en Gaule seray paralitique, Jusques a ce que tu m'abuveras, Eustaces sui; qui de mon plant aras. Mais pran en gré les euvres d'escolier Que par Clifford de moy avoir pourras, Grant translateur, noble Geffroy Chaucier.

\section{L'Envoy}

Poete hault, loenge d'escuirie, En ton jardin ne seroye qu'ortie. Considere ce que j'ai dit premier: Ton noble plant, ta douce melodie, Mais pour sçavoir, de rescripre te prie, Grant translateur, noble Geffroy Chaucier.
(Socrates, full of philosophy,

Seneca in morality, Aulus [Gellius] in his practice, Great Ovid in your poetry, Concise in speech, wise in rhetoric, An eagle on high, who, by your understanding, Illuminates the kingdom of Aeneas,

The island of the Giants, that of Brutus, and who has Sown the flowers and planted the rosebush, You will take the language to those who do not know it,

Great translator, noble Geoffrey Chaucer.

You are the earthly god of love in Albion and of the Rose, in the angelic land/land of the Angles which [was] of Saxon Angela, and then 'Angleterre' flourished - that name derives from her [i.e. Angela], Last in the etymological series $-{ }^{10}$

You translated the book [i.e. the Rose] into good English, And for a long time now you have been constructing an orchard,

For which you have asked for plants from those Who write poetry to create authority, ${ }^{11}$

Great translator, noble Geoffrey Chaucer.

And for this reason I ask to have from you A genuine draught from the fountain of Helicon,

The source of which is entirely under your jurisdiction, That I may quench with it my fevered thirst; $\mathrm{I}$, who will remain paralysed in Gaul Until you let me slake my thirst,

Am Eustache; you will have my plants.

But take these works of a schoolboy, which you will be able To have from me via [Lewis] Clifford, in good spirit,

Great translator, noble Geoffrey Chaucer.

Envoy

Lofty poet, famed among the squires, I would be but a nettle in your garden. Consider what I said at the beginning: Your noble plant, your sweet melody. But I do beg you for official confirmation of receipt, Great translator, noble Geoffrey Chaucer.)

The heavy use of allusions to figures from antiquity was a well-established formal feature of the so-called 'mythographic' formes fixes ballades, practised by the likes of Machaut, Froissart, Deschamps, Gower, and Chaucer, which rely heavily 
on exempla derived from Graeco-Roman mythology. In this ballade, however, the specific exempla invoked by Deschamps are hardly haphazard. As James Wimsatt first noted, several of them closely resonate with the exempla used in a pair of slightly earlier ballades between Philippe de Vitry and Jean de le Mote, which stage a debate over the propriety of translating and composing poetry on English soil. Also densely packed with classical allusion, these ballades are about Le Mote's move from Hainault over to England, most likely in the retinue of Philippa of Hainault, whose father Le Mote served. ${ }^{12}$ Vitry, who resides outside of Paris, condemns Le Mote's move in the harshest terms, and Le Mote offers a spirited defence of his actions in return. ${ }^{13}$

\section{Philippe de Vitry to Jean de le Mote:}

De terre en Grec Gaule appellee, Castor [fuitis, fuyans] comme serfs En Albion de flun nommee,

Roys Antheus devenus serfs.

Nicement sers

Quant sous fais d'anfent fains amer

D'amour qu'Orpheus ot despite.

Lou, tu n'as d'amour fors l'amer,

En Albion de Dieu maldicte.

T'umbre de fuite yert accuse Par Radamancus le pervers Et de Roy Minnos condempnee

A vij tours de queue a revers.

Eacus pers

Contraindra ta langue a laper,

Comme de renoié traïte,

De Flagiton, l'amere mer,

En Albion de Dieu maldicte.

Certes, Jehan, la fons Cirree

$\mathrm{Ne}$ te congnoit, ne li lieux vers

Ou maint la vois Caliopee.

Car amoureus diz fais couvers

De nons divers,

Dont aucun enfés scet user

Com tu, qui ne vaulz une mite

A Pegasus faire voler

En Albion de Dieu maldicte.
(Out of the land called Gaul in Greek,

Runaway beaver, fleeing like a slave,

To Albion named for the river,

Violent Antheus having become a stag. ${ }^{14}$

You serve foolishly

When childishly you feign to love

With a love that Orpheus despised.

Wolf, you have of love nothing but the bitter part

In Albion cursed by God.

Your shade will be accused of flight

By the cruel Rhadamanthus

And condemned by King Minos

With seven turns of his tail back.

Pallid Aeacus

Will force your tongue to lap,

Like that of a renegade traitor,

From Phlegethon, the bitter sea,

In Albion cursed by God.

Certainly, John, the fountain of Cirrha

Does not know you, nor the green place

Where the voice of Calliope remains.

For you make love poems filled

With diverse names,

Which any child knows how to use

Like you, who are not the slightest bit worthy

Of making Pegasus fly

In Albion cursed by God.) ${ }^{15}$

\section{Jean de le Mote to Philippe de Vitry:}

O Victriens, mondains Dieu d'armonie, Filz Musicans et per a Orpheus, Supernasor de la fontaine Helye, Doctores vrays, en ce pratique Auglus, Plus clers veans et plus agus qu'Argus, Angles [en chant], cesse en toy le lyon; $\mathrm{Ne}$ fais de moy Hugo s'en Albion Suis. Onques n'oÿ ailleurs bont ne volee;
(O man of Vitry, earthly god of harmony,

Son of Musicans and peer of Orpheus,

Naso-on-High of the fountain of Helicon,

A true doctor, an Aulus Gellius in this practice,

More clearsighted and more sharp than Argus,

An angel in song, restrain the lion in you;

Do not make a Hugo out of me because I am in Albion. ${ }^{16}$

I've never heard that said anywhere in any way; 
Ne je ne sui point de la nacion

De terre en Grec Gaulle de Dieu amee.

Mais [foleanse] enluminans envie Par fauls procés raportés d'Oleus T'a fait brasser buvrage a trop de lie Sur moy, qui ay de toy fait Zephirus, Car en la fons Cirree est tes escus, Tous jours l'ay dit sans adulacion. Or m’as donné Acu pers Flangiton, Fleuve infernal, et les vij tours d'entrée Sept tourmens sont. Je ne vueil pas tel don De terre en Grec Gaulle de Dieu amee.

Contre mal bien [ferme] sers en Albie, Castor, [ne leus], ne roys serfs Antheus. Et si li roys Minos enquiert ma vie, Il trouvera Eclo et ses vertus Pour contrester contre Radannatus, S'il m'acusoit d'aucune traïson.

[N'ains noms ne mis en fable n'en] chançon Qui n'ait servi en aucune contree.

Sy te suppli, ne banny mon bon nom

De terre en Grec Gaulle de Dieu amee.
And I am not at all from the nation

Of the land in Greek called Gaul, loved by God.

But folly which makes envy burn

Through false information about me reported by Aeolus Has made you brew a drink with too many dregs, Me who has made of you a Zephirus,

For your escutcheon is in the fountain of Cirrha, I have always said it without adulation.

Now you have given me the pallid Aeacus of Phlegethon, The infernal river, and the seven turns at the entrance Are seven torments. I do not wish for such a gift From the land in Greek called Gaul, loved by God.

Against evil I staunchly serve in Albion,

No beaver, nor wolf, nor the violent stag Antheus. And if king Minos investigates my life, He will find Echo and her powers To oppose Rhadamanthus, If he did accuse me of any treason.

Nor have I ever put any name in fiction or in song Which might not have served in any region.

So I entreat you, do not banish my good name

From the land in Greek called Gaul, loved by God.) ${ }^{17}$

Wimsatt identifies several key parallels between this earlier ballade exchange and Deschamps's address to Chaucer:

Le Mote to Vitry (line I): O Victriens, mondains Dieu d'armonie Deschamps to Chaucer (line II): Tu es d'amours mondains dieux en Albie

Le Mote to Vitry (line 3): Supernasor de la fontaine Helye (supernasor: Publius Ovidius Naso) Deschamps to Chaucer (line 3): Ovides grans en ta poeterie

Le Mote to Vitry (line 4): Doctores vrays, en ce pratique Auglus Deschamps to Chaucer (line 2): Seneque en meurs et Auglux en pratique

Le Mote to Vitry (line 13): T'a fait brasser buvrage a trop de lie Deschamps to Chaucer (lines 2I-3): A toy pour ce de la fontaine Helye

Requier avoir un buvraige autentique

Dont la doys est du tout en ta baillie

Deschamps's particular rendering of 'fontaine Helye' for Helicon suggests an acquaintance with Le Mote's text, where 'fontaine Helye' also makes an appearance. ${ }^{18}$ Furthermore, in one of his more overtly anti-English other lyrics, in which Deschamps hopes fervently for England's total destruction, he has the line: 'En esperant, que la redempcion / De Gaule en grec sur la terre d'Albie / Voy approchier ...' (lines 3-5, emphasis added: hoping that I see coming on the land of Albion the redemption of Gaul in Greek). ${ }^{19}$ This odd construction 'Gaule en grec' recalls Vitry's address to Le Mote: 'De terre en grec Gaule appellee' (line I, emphasis added: 'Of the land called Gaul in Greek'), as well as Le Mote's refrain, which rewords that line from Vitry into: 'De terre en Grec Gaulle de Dieu amee' 
(emphasis added: 'Of the land Gaul in Greek loved by God'). ${ }^{20}$ Le Mote also calls Albion 'Albie' in line 2I of his response to Vitry. Moreover, in another ballade describing hell, Deschamps invokes the infernal river Phlegethon and the judges Aecus and Rhadamanthus, also mentioned by Vitry. ${ }^{21}$

These parallels between the Vitry-Le Mote exchange and the 'Ballade to Chaucer' have gone largely unnoticed until Butterfield's recent suggestion that these phrases come up because Deschamps is occupying a similar, if not even more rigid, position to Vitry on the subject of cross-Channel literary activity. After all, she argues, like Vitry, Deschamps too is a French poet on sovereign French soil writing to a marginalized figure living in a country that, elsewhere in his poetry, he notoriously fears and despises. As Butterfield concludes: 'We saw that de le Mote was accused of treachery for speaking French for the English. Chaucer, in a similar vein, was accused by Deschamps of being a translator. ${ }^{22}$ Yet, if we look closely at the dominant parallels, we notice that they come not from Vitry's address to Le Mote, but from Le Mote's response. Deschamps does not cull his allusions from Vitry's condemnation of Le Mote's move to England, but instead from Le Mote's defence of life in England. Deschamps's counterintuitive move suggests that we need to look more closely at the content and stakes of this earlier exchange of invectives.

In fact, the Vitry-Le Mote exchange revolves around a question deeply relevant to Deschamps's discussion of Chaucer: should francophone poetry flourish in England and, if so, what forms should this poetry take? Vitry opens with the violently emasculating image of Le Mote's bolting for England like a beaver, an animal reputed in bestiary lore for biting off its own testicles when pursued. ${ }^{23}$ Vitry then prophesies that Le Mote's move to England will damn his soul to hell where he will be punished as a 'renoié traïte' ('a renegade traitor') by the three judges of the Underworld, Minos, Aeacus, and Rhadamanthus. Remarkably, Vitry's description of Le Mote's fate appears to be the earliest known allusion in French to Dante's Inferno (V.I-20). ${ }^{24}$ As F. N. M. Diekstra has observed, Vitry has Minos coil his tail seven times; since Minos stands at the second circle and each coil indicates how much further down the soul must go (Inferno, V. IIf.), Vitry is having Minos send Le Mote to the ninth circle, famously reserved for traitors. ${ }^{25}$ The intensity of this charge - that Le Mote's departure for England is nothing short of treason, punishable by eternal hellfire - reveals a strong political flavour in Vitry's accusation. Records indicate that Le Mote was receiving an annuity from Edward III in 1338, one year after Edward's declaration of war on France for rights to the French throne, and he spent the rest of his life at the English court. ${ }^{26}$ While the exact date of the Vitry-Le Mote exchange is uncertain, Nigel Wilkins identifies a terminus post quem based on the reference to 'Hugo' in Le Mote's response, an allusion to Vitry's motet Cum statua / Hugo, composed after 1356. ${ }^{27}$ The date of Le Mote's death is unknown, but a contemporary lists Le 
Mote after Vitry and Machaut as one of the foremost living poets of the day in 1350. ${ }^{28}$ Vitry died in 136I. The exchange is thus datable to the late I350s, which saw the disastrous capture of John II at the Battle of Poitiers in 1356 and the campaigns of devastation of the French countryside by Edward the Black Prince and Edward III and by the mercenary battalions of the Grandes Compaignies. ${ }^{29}$ Vitry's denunciation of Le Mote as a traitor for living in England in the midfourteenth century thus cannot but invoke the larger political context of the Hundred Years War.

In addition to these political charges, however, Vitry simultaneously levels an aesthetic critique of Le Mote's poetry. He says that Orpheus would despise Le Mote's work (lines 7f.) and that Le Mote has never been to the 'fountain of Cirrha', that is, the fountain of Hippocrene in Helicon, home to the Muses (lines I9f.). ${ }^{30}$ In leaving continental Europe, then, Le Mote has also left Mount Parnassus. It is not at this point yet clear why Vitry dislikes Le Mote's poetry, but the following lines shed light on Vitry's displeasure:

... amoureus diz fais couvers

De nons divers,

Dont aucun enfés scet user

Com tu ...

\author{
(... you make love poems filled \\ With diverse names, \\ Which any child knows how to use \\ Like you ....) (lines 22-5)
}

Le Mote is not only writing poetry in enemy territory, he is also writing in an unsophisticated, puerile manner, simply stuffing his poetry with 'diverse names'. By labelling Le Mote's work childish, Vitry seems to be outlining a particular understanding of what forms poetry ought to take, as if there is some kind of literary tradition that Le Mote is flouting.

A representative example of Le Mote's own work reveals what Vitry is intending by his statement. It is a highly hermetic text, brimming with what Vitry aptly terms 'diverse names':

\footnotetext{
Ras nonpourquant des bestes sauvagines Est estranglee, et Thisbe est escorchie, Et Helainne est a toutes discipline[e] Par trop amer, et pendue est Helye Par les cheveux; Lucidaire est bruye, Flore, Yde, Edee [v?] ont en mer tout contraire, Tholomee, Asse firent jaloux detraire, Si que d'amours n'orent fin ne entrée Ras, Tisbe, Helainne, Elye, Lucidaire, Flore, Yde, Edee, Asse ne Tholomee.
}

\author{
(Nevertheless Ras is strangled \\ By savage beasts, and Thisbe is flayed, \\ And Helainne is beaten by everyone \\ For loving too much, and Helye is hanged \\ By her hair; Lucidaire is burned, \\ By contrast, Flore, Yde, and Edee go into the sea (?); \\ Tholomee and Asse had the jealous one torn apart, \\ And so of love neither Ras, Tisbe, Helainne, \\ Elye, Lucidaire, Flore, Yde, Edee \\ Asse nor Tholomee had no end and no beginning. $)^{31}$
}

Constituting various allusions to what looks like mythography, these names certainly appear to justify Vitry's complaints, whether through their unfamiliar context or their downright obscurity. Ras, Lucidaire, and Edee, for example, are names of minor characters in a series of late medieval French Alexander romances, to which Le Mote had written a continuation, Le Parfait du paon, in 1340. ${ }^{32}$ When Le Mote does use recognizable exempla, he alters the well-known 
stories, so that Thisbe ends up flayed to death and Helen is beaten for her love. ${ }^{33}$ Mixing established traditions and perhaps even inventing wholly new ones, Le Mote seems to stray from conventional uses of classical mythography, just as he has strayed out of continental Europe into England. Vitry explicitly maps 'correct' poetic praxis onto 'correct' geographic location in his final lines, when he assures Le Mote that he will never succeed 'a Pegasus faire voler / En Albion de Dieu maldicte' (lines 26f.: 'in making Pegasus fly in Albion cursed by God'). ${ }^{34}$ In associating Le Mote's outlandish work with his choice to move across the Channel, Vitry's complaint emerges as a suspicion of the kinds of newfangled poetry that may be produced in distant territories when removed from the rigours of centralized French poetic production.

Le Mote's response, however, patently displays that one can produce French poetry in England that is wholly on a par with continental French productions. His rejoinder contains a series of wholly legible classical allusions - Orpheus, 'fontaine Helye', Echo - that are a far cry from the whimsical fancy he displays in his other poetry. These legible allusions further contain several pointed barbs: for example, Le Mote goes on to praise Vitry as being 'plus clerc veans et plus agus qu'Argus' (line 5: 'more clearsighted and more sharp than Argus'). Vitry, astute reader of the classical tradition that he claims himself to be, ought surely to recognize this phrase as a dubious compliment, for in the Metamorphoses Ovid recounts how Mercury lures the hundred-eyed Argus to sleep and then to his death (I.668-88). By emulating Vitry's more conservative approach towards using allusions drawn from antiquity, Le Mote neatly renders void the charge that his own use of classical allusion is puerile.

Le Mote goes on to mount a defence of his creative rewriting of antiquity that gets at the very heart of Vitry's demi-political, demi-aesthetic objections:

\footnotetext{
... je ne sui point de la nacion

(... I am not at all from the nacion

De terre en Grec Gaulle de Dieu amee.

Of the land in Greek called Gaul, loved by God.) (lines gf.)
}

Le Mote's use of the word 'nacion' here merits close attention. The Dictionnaire $d u$ moyen français identifies a profound transformation in this word's definition and usage over the course of the fourteenth century. Sources dating from the early to mid-fourteenth century tend to use the term in the sense of birth, extraction, origin, or lineage, but from the middle third and particularly by the end of the fourteenth century, the term is also found increasingly used in the sense of the people or population of a particular town, city, or region, united by territory and/or language. Le Mote is writing in the early to mid-fourteenth century, which would suggest that he is employing the term in its agnatic sense of birth or lineage, though it is possible that the slightly later sense of people or population is already coming into play. ${ }^{35}$ Read in the context of the rest of his response to Vitry, however, Le Mote's use of 'nacion' - 'I am not at all from the nacion, of the land in Greek called Gaul, loved by God' - offers a unique 
definition of the term that points to Le Mote's nuanced understanding of his own cultural and political relationship to France.

Le Mote hails from and has spent his professional career in Hainault and England, both francophone territories but neither subject to French sovereign rule: England was, of course, at war with France, and Hainault was a vassal state of the Holy Roman Empire. Le Mote is claiming, therefore, that Vitry cannot accuse him of political betrayal because Le Mote is not a French 'national', not, in other words, a French political subject. Although he patently shares linguistic and cultural ties with the residents of the French sovereign state, Le Mote claims no affinity with France, and 'nacion' is thus for him only a geopolitical entity, devoid of its earlier, broader cultural definitions. If he is not a French 'national', then his move to England cannot be considered traitorous, and any literary activities performed in England cannot be condemned. Le Mote thus offers Vitry a very different conception of what being 'French' means and of where and how 'French' poetry should be written. His defence of writing in England is further expanded into a defence of writing anywhere, as he goes on to say (emphasis added):

N'ains noms ne mis en fable n'en chançon, Qui n'ait servi en aucune contree.
(Nor have I ever put any name in story or in song Which might not have served in any region.) (lines 27f.)

While Vitry had conjoined Le Mote's service in an enemy court with his service to Orpheus, claiming that Le Mote serves poetry just as badly as he serves his country, Le Mote has here flipped this statement around. He has never used any name, he says, that has not served equally well in any region, resisting Vitry's exclusionary geography that is casting his outré verse as the unbridled literary practice of the European hinterlands. Le Mote is suggesting that one does not need to be a good French political subject to be a good French poet.

The Vitry-Le Mote exchange presents two opposing views regarding the notion of a francophone culture in England that plays out over the question of how properly to use 'noms diverses', or references to classical antiquity. For Vitry, poetry produced across the Channel is beyond the pale - politically and, therefore, also aesthetically - whereas Le Mote seems to be imagining a broader space of 'francophonie' that subsumes the geopolitical rifts produced by the ongoing war and permits mythography to run riot. Classical allusion thus emerges in the Vitry-Le Mote exchange as a means of policing wartime regional borders. Its role as key criterion in this exchange for judging the value of poetry produced across the Channel suggests that fostering francophone culture in England involves far more than the translation from one language to another; equally important is the proper translation of forms.

So how to take Deschamps's surprising decision to align himself not with Vitry against francophone culture in England but, rather, with Le Mote and for that culture? It could, of course, be intended ironically; after all, Deschamps's 
citations - earthly god, great Ovid, Aulus Gellius - all hearken back to moments in which Le Mote is in the process of elaborately flattering Vitry. It is possible that Deschamps is just subtly mocking Chaucer by addressing him in the same terms as Le Mote does his aggressor. The exact phrases that Deschamps is borrowing from Le Mote, however, are hardly random: they are exempla that Le Mote, as we recall, deploys strategically in order to demonstrate that, while he may play fast and loose with some of his classical allusions, he has an excellent knowledge of classical antiquity. Le Mote thereby implies that his rewriting of the auctores should not be chalked up to simple literary ignorance but, rather, represents a practice of informed and sophisticated literary revision in the service of his vision of a geographically extensive francophone culture. Otherwise put, Deschamps invokes the very places in Le Mote's response that illustrate what is most at stake in the Vitry-Le Mote debate over cross-Channel translation.

Chaucer, then, is a Socrates, a Seneca, an Ovid, and a 'grant translateur' because Deschamps too understands the reception of classical antiquity as being a key component in evaluating the merits of a cross-Channel poet who translates from his francophone contemporaries. Furthermore, although Deschamps, like Vitry, resides in France, he plainly does not share Vitry's apprehensions regarding the flourishing of a French-derived literary culture in England. Instead, his drawing on Le Mote's side of the exchange reveals a Le Motian vision of a rich 'francophonie' extending beyond France. Deschamps, we note, also uses the phrase 'mondains dieux d'armonie' in reference to Guillaume de Machaut, in his famous lament on Machaut's death (line I), in which he also calls Machaut the stream and channel of the 'fons Cirree' and the 'fontaine Helye' (lines 9f.). ${ }^{36}$ These echoes between Deschamps's celebration of Machaut and his address to Chaucer underscore the significance of his reuse of these epithets from Le Mote's reponse and their undoubted laudatory nature. We do not need to reconcile Deschamps's anti-English political sentiments elsewhere with the positive tone of his address to Chaucer nor look for periods of political calm between the two countries in order to explain this ballade, for Deschamps's address to Chaucer is about praising poetry's ability to translate across the political rifts between England and France. Deschamps values Chaucer precisely because, not in spite, of the political divisions between their countries.

Deschamps's engagement with Le Mote's response further suggests that translation is for him, as for Vitry and Le Mote, not only about successfully crossing war-torn geographical divides, but also about navigating the crosstemporal divides that separate contemporary francophone literature from its classical heritage. In drawing on Le Mote's side of the exchange, Deschamps demonstrates that he too values dynamic rewritings of classical antiquity that develop and reconfigure, rather than simply reiterate, existing classical allusions. If for Vitry and Le Mote, however, working with classical antiquity is a means 
of evaluating one's place in the culturo-political landscape of late medieval francophone Europe, then Deschamps's address to Chaucer develops the role of classical allusion in a poet-translator's euvre still further. For Deschamps, the use of classical allusion is no longer simply about where one is in francophone Europe, but where one stands in the literary pantheon of great poets stretching from antiquity to the present day.

\section{Planting poetry on both sides of the Channel}

That Deschamps's address to Chaucer is to be read as a poem of sincere praise, articulated in the very midst of and despite the ongoing Hundred Years War, is still more evident from the second intertext raised by Deschamps's particular choice of classical exempla. As André Crepin has noted in passing, there are several striking parallels between Deschamps's ballade to Chaucer and another ballade by Deschamps. ${ }^{37}$ In this other work, Deschamps reflects on his own lifelong literary achievements as well as on his own place within literary history. The dominant metaphor that Deschamps uses to discuss his literary career is of a garden:

Doulz Zephirus, qui faiz naistre les flours, Printemps, Este, Autompne, et Aurora, Plourez o moy mes dolentes doulours, Et le jardin que jadis laboura

Fons Cireus, ou Galiope ouvra, Qui de ses fleurs avoit fait un chapel Si odorant, si precieus, si bel

Que de l'odour pouoit guarir touz maulx Quant un fort vent le print par cas isnel: S'ainsi le pers, c'est trespovres consaulx.

Continuelz fut vint ans mes labours Aux fleurs semer ou Ovides planta De Socrates et Seneque les mours, Et Virgiles mains beaus mos y dicta, Et Orpheus ses doulz chans y nota, Poeterie fut au tour du sercel, Rhetorique le fist ront comme annel, Lettres y mist et les noms de plus haulx Si plaisamment que maleureus m'appel: S'ainsi le pers, c'est trespovres consaulx.

Si pri Juno, la deesse d'amours, Et a ce vent qui mon fruit ravi a, Aux dieux de l'air qu'ilz me facent secours, $\mathrm{Ou}$ autrement tout mon fait perira, Car mon las cuer james rien n'escripra Et ne vouldra riens faire de nouvel. Conseilleiez vous a Eustace Morel, Si me rendez mes choses principaulx, Ou me bailliez copie du jouel: S'ainsi le pers, c'est trespovres consaulx.
(Sweet Zephirus, who makes the flowers come out, Spring, Summer, Fall, and Aurora,

Mourn with me my painful suffering,

And [mourn] the garden, which the fountain of Cirrha once

Cultivated, where Calliope worked,

[And him,] who had made a wreath of its flowers,

So fragrant, so precious, so beautiful,

That with its fragrance it could heal all suffering,

When a strong wind took it by sudden chance:

If I have thus lost it, it is a miserable situation.

I laboured continuously for twenty years

To sow flowers where Ovid planted

The virtue of Socrates and Seneca,

And Virgil wrote many beautiful words there,

And Orpheus composed his sweet songs there.

Poetry was around the ring [of the wreath],

Rhetoric made [the wreath] round like a circlet,

I put letters there and the names of the loftiest

So easily that [now] I call myself wretched:

If I have thus lost it, it is a miserable situation.

So I pray Juno, [and] the goddess of love,

And this wind which snatched my fruit,

And the gods of the air that they help me,

Or otherwise all of my work will perish,

For my weary heart will never write anything again

And would not want to make anything new.

Aid Eustache Morel,

And so return to me my most important things,

Or send me a copy of the precious object:

If I have thus lost it, it is a miserable situation. 
L'envoy

Prince, avisez mes piteuses clamours Et faictes tant que mes chapeaux sont saulx, Car moult y a des diverses coulours:

S'ainsis le pers, c'est trespovres consaulx.
Envoy

Prince, consider my piteous plaints

And make it so that my wreaths stay intact, ${ }^{38}$

For there are so many different poems there:

If I have thus lost it, it is a miserable situation. $)^{39}$

Deschamps thus describes both himself and Chaucer as performing a remarkably similar activity: they both cultivate flower gardens. Rendered in Latin as 'Fons Cireus', but still recognizable as our fountain of Cirrha, this reference also instantly evokes a now familiar poetic topography. Calliope, mother to Orpheus and muse of epic poetry (who also makes an appearance in Vitry's address to Le Mote), is to be found in Deschamps's garden, to which Ovid has lent a helping hand in fostering the words of Socrates and Seneca, and which Virgil and Orpheus have used as a writing retreat. The cast of characters is, with one exception, identical to that of the 'Ballade to Chaucer': Ovid, Socrates, Seneca, and Virgil recur in both poems, and where Deschamps's garden has Orpheus, the mythic inventor of music, the ballade to Chaucer has Aulus Gellius, a figure that directly echoes Le Mote's response to Vitry. Deschamps further describes the wreath culled from his garden as having been formed into a perfect shape by 'poeterie' and 'rhetorique' (lines I6f.), the same two terms that he applies to Chaucer, who is a great Ovid in his 'poeterie' and wise in his use of 'rhetorique' (lines 3 f.). In both texts, that word pair poeterie/rhetorique occurs in the same order and is emphasized syntactically by its placement in the emphatic first position in Deschamps's poem about himself and, by contrast, in the emphatic rhyme position in his ballade to Chaucer. ${ }^{40}$ Deschamps seems to be forging a powerful parallel between his own lifelong literary achievements and those of Chaucer.

The stakes behind creating this parallel emerge, once again, from the uses of classical allusions - and 'noms diverses' in general - in both poems. In the lyric about himself, after having named Ovid, Socrates, Seneca, Virgil, and Orpheus, Deschamps goes on to give his own full birthname when he asks, in line 27, that Juno, Venus, and the gods aid 'Eustace Morel'. ${ }^{41}$ Deschamps gives his own name as sixth after listing the five figures that he describes as working and residing in his literary garden. Placing oneself sixth is a clear instance of what David Wallace has termed the 'sixth of six topos', a poetic device whereby an author lists himself, or is listed, as the last member within a handpicked canon of five known literary figures from the past, of which he becomes, by virtue of his position at the very end, its evident heir and pinnacle. We might recall Dante's Inferno IV, when Virgil brings Dante to the shades of Homer, Ovid, Horace, and Lucan, and they welcome him as the sixth poet in their midst (lines 82-96). Similarly, Boccaccio in the Filocolo hopes his book will follow in the footsteps of Virgil, Lucan, Statius, Ovid, and Dante (2.376-8). The topos is also used by Chaucer in Troilus and Criseyde, when he wishes his work might render homage to Virgil, Ovid, Homer, Lucan, and Statius (5.I79If.). ${ }^{42}$ It also occurs 
at the midpoint of the Roman de la Rose where Jean de Meun places himself as sixth within a line-up of the five literary greats that have preceded him: Tibullus, Gallus, Catullus, Ovid, and Guillaume de Lorris (lines I0969-IIO32).43

In the first stanza of his ballade to Chaucer, meanwhile, Deschamps calls Chaucer a Socrates, a Seneca, an Aulus Gellius, and an Ovid. In lines 5-7, he names Chaucer an eagle who has illuminated 'le regne d'Eneas / L'Isle aux Geans, ceuls de Bruth' ('the kingdom of Aeneas, the Island of the Giants, those of Brutus'). This expansive formulation simultaneously invokes Virgil's Aeneid as well as the afterlife of that text in the originary myth laid out by Geoffrey of Monmouth in the Historia regum Britanniae and translated into Anglo-Norman by Wace, an aptly palimpsestic reference to England's own translation of its classical inheritance. After listing Socrates, Seneca, Aulus Gellius, Ovid, and, via this circuitous literary reference, Virgil/Geoffrey/Wace, Deschamps proceeds to place 'grant translateur, Geffroy Chaucier' as the sixth and final name within the stanza. ${ }^{44}$ Deschamps thus presents both himself and his English contemporary as the sixth figures within an almost identical literary line-up, from which, following the conventions of that literary device, they emerge as twain in their status as heirs to antiquity. The dating of Deschamps's autobiographical poem cannot, unfortunately, be ascertained with any certainty, rendering it difficult to plot the direction of influence between Deschamps's characterization of himself and his characterization of Chaucer. Regardless of which lyric came first, however, Deschamps clearly appears to be placing Chaucer on equal footing with his own self - and precisely in Chaucer's role as 'grant translateur'. By presenting both himself and Chaucer as mutual recipients of a shared classical cultural legacy, Deschamps emphasizes again that the value of a francophone poetry on English soil resides not just in its synchronic translations into 'bon anglès', but, far more importantly, in its diachronic translations from antiquity.

In this way, Deschamps's praise of his own achievements alongside those of Chaucer speaks to that vital role played by the use of classical allusion in evaluating the growth and transmission of francophone culture that we have already observed in the Vitry-Le Mote exchange. In its inclusion of the fountain of Cirrha, as well as in its mention of Orpheus and Calliope, Deschamps's poem about himself explicitly recalls Vitry's and Le Mote's discussions of the proper placement of Helicon and Parnassus in a war-torn francophone Europe. Emergent, then, from Deschamps's evaluation of himself alongside his fellow English poet, as well as from the earlier Vitry-Le Mote exchange, is the sense that translation is not only a vital form of literary activity but is in fact integral to the establishment and maintenance of one's literary fame. Deschamps praises Chaucer because he is a translator and because translation activity does vital cross-cultural work, at once geographic and temporal. And yet, while Deschamps offers to send his own work to Chaucer, modestly claiming it is but 'euvres d'escolier' (line 28: 'works 
of a schoolboy') and an 'ortie' (line 32: 'a weed') for Chaucer's garden, and asks Chaucer to send back some official confirmation that he has received the poetry (line 35), he does not ask for any of Chaucer's own poetry in return. For all its celebration of cross-Channel exchange, Deschamps's ballade appears oddly onesided. Yet while it might seem that Deschamps is simply employing a humility topos here with regard to his own works, there is more at stake, I suggest, in this self-characterization of his work as 'euvres d'escolier' and 'ortie'.

\section{Helicon in exile}

Vitry and Le Mote's heavy reliance on Ovid in their debate over the relationship between political and cultural topographies cannot but recall Ovid's own poetry of exile, the Tristia and the Epistulae ex Ponto, and Margaret Bent has already demonstrated Vitry's certain knowledge of Ovid's Epistulae. ${ }^{45}$ At the same time, neither Vitry nor Le Mote overtly treat exile within their exchange: Vitry compares Le Mote to 'Antheus', possibly to be understood as Actaeon, and to an emasculated beaver. ${ }^{46}$ These images, however, are of flight, rather than exile specifically, and Le Mote's proud defence of his life in England certainly does not present the image of a poet in exile. Instead, it is Deschamps who pulls the Ovidian layer out of the Vitry-Le Mote exchange and reshapes it into a poetics of exile, a poetics in which the poet in exile turns out to be - it is suddenly suggested - Deschamps himself.

In the second letter of book IV of Epistulae ex Ponto, Ovid writes to a fellow poet named Severus who is, evidently, back in Rome. Ovid goes on to describe this Severus as reaping the richest harvest of all those who cultivate Helicon (lines IIf.). For this reason, Ovid avows, he is unable to send Severus any poetry, for it would be like sending honey to Aristaeus, wine to Bacchus, or like adding leaves to a forest (lines 9-13). In other words, it would be a wholly superfluous action, an idea that resonates with Deschamps's declaration that his works would be but weeds in Chaucer's garden. Ovid's detail of the forest further echoes Deschamps's mention of Chaucer's having a 'verger' (line i7: 'orchard'). Ovid goes on to develop further the image of cultivating on Mount Helicon as a metaphor for poetic activity: he is unable to send Severus any poetry because the soil in his exile is arid and does not yield to his weak plough (line I6). Indeed, Ovid's capacity for poetic production has become as blocked as a fountain choked by mud (lines 17-20), a line that reminds us of Deschamps's claim that he will remain paralysed in Gaul, unable to drink from the fountain of Helicon (lines 35 f.). Ovid concludes by asking Severus, who drinks freely of the 'Aonius fons' (line 47: 'the Aonian spring'), to send over some of his more recent work (lines 49f.). ${ }^{47}$ Deschamps, meanwhile, describes himself as parched from thirst, for the 'fontaine Helie' is entirely in Chaucer's jurisdiction (lines 30-4). 
Deschamps's tertiary intertext adds a brand new dimension to the references to Ovid in his address to Chaucer as well as in his discussion of his own French poetic garden. On the one hand, by means of these allusions, Deschamps seems to present himself in Ovidian exile, suffering on arid French soil while Chaucer, like Severus, enjoys the nourishing waters of Helicon. On the other hand, this exilic intertext is informing a work in which Deschamps has already explicitly termed Chaucer a 'great Ovid'. Deschamps thus appears to be suggesting that he and Chaucer are both Ovids within their respective territories: Chaucer as the great Ovid in England, and Deschamps as the exiled Ovid in France. At the same time, however, Deschamps has largely rewritten Ovid's letter to Severus since, rather than reproduce Ovid's request for poetry from Severus to comfort him in barren exile, Deschamps instead sends poetry to Chaucer and requests official confirmation of receipt but no further poetry in return. Thus, the great Ovid in England has access to Helicon but no poetry to give, whereas the exiled Ovid in France is, in fact, a productive Ovid, albeit the work is all weeds and juvenilia. Where, then, is Helicon and where is exile: in England or in France?

The answer, Deschamps seems to suggest, is both. If all poets are, by virtue of their citation of classical allusion, always already translators, then all poets are always already in exile from their originary texts. While Deschamps's selfabnegating characterization of his own poetry as 'euvres d'escolier' ('schoolboyish works') is an evident humility topos, it also points straight back to Vitry's main critique of Le Mote's cross-Channel poetry:

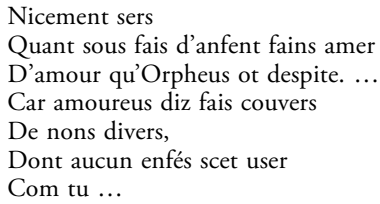

(You serve foolishly
When childishly you feign to love
With a love that Orpheus despised ...
For you make love poems filled
With diverse names,
Which any child knows how to use
Like you ...) (lines $5-7,22-5$ )

Vitry, as we have seen, uses the term 'childish' to demonstrate his condemnation of Le Mote's inventive use of pseudo-mythography on the English side of the Channel and to express concerns over the new forms that poetry can take in the process of translation. Behind Deschamps's praise of Chaucer and his comparison of Chaucer to his own self as both translators of antiquity thus lies that larger question we already saw with Vitry and Le Mote: in what ways does translation practice change poetry and to what extent does it change poetry for the better? Deschamps's modesty topos thus evokes both Vitry's claims about Le Mote's geographically, politically, and aesthetically distant work and Ovid's self-abnegating characterization of the poetry he is producing in distant exile. Deschamps's modesty topos speaks to a lingering concern over the potential loss of poetry in translation and the geographic, temporal, and cultural distances that poetry attempts to breach but may not always succeed in traversing. 
Deschamps's anxiety over the potential loss that comes with translation further registers in the poem about his poetic garden that represents his own translation practice from antiquity. In this poem, we recall, Deschamps laments the snatching of the poetic wreath that he has culled from his garden by the wind:

... Qui de ses fleurs avoit fait un chapel Si odorant, si precieus, si bel

Que de l'odour pouoit guarir touz maulx Quant un fort vent le print par cas isnel: S’ainsi le pers, c'est trespovres consaulx.
(... [And him] who had made a wreath of its flowers, So fragrant, so precious, so beautiful,

That with its fragrance it could heal all suffering, When a strong wind took it by sudden chance:

If I have thus lost it, it is a miserable situation.) (lines 6-Io)

Read in the context of the questions concerning translation posed by the 'Ballade to Chaucer' and the Vitry-Le Mote exchange, the lost wreath in this poem points to another representation of Deschamps's larger concerns over the potential loss of poetry in translation. The wreath is gathered from the virtues of Socrates, Seneca, et al. that have been planted in the garden and has been shaped by poetry and rhetoric, suggesting that it is a product of Deschamps's translation from antiquity. Its loss by sudden misfortune echoes Deschamps's concern in his address to Chaucer that his poetry will turn into weeds once planted into Chaucer's garden: it is a concern over the inherent mutability of language that pulls sources out of their originary contexts and reshapes them into new forms that render those sources unrecognizable or, worse, suddenly ephemeral.

The Ovidian exilic intertext of Deschamps's poem thus casts a slight pall over Deschamps's seemingly unmitigated praise of Chaucer in reminding us that with translation invariably comes loss, and that translation loss threatens the author with exile and potential ultimate obscurity. In emphasizing the centrality of classical allusion to the question of Anglo-French translation, Deschamps makes fully clear what it means to be a 'grant translateur' and why that appellation is one of praise: the great translator translates successfully to posterity, thus enshrining his position in a literary pantheon. Deschamps's 'Ballade to Chaucer' is not about whether or not Chaucer was being read on the Continent: it is about Chaucer's successful transmission of classical antiquity for the endurance of his own literary fame and Deschamps's desire that if he too can be translated to Chaucer's garden, then he too will be part of this flowering literary lineage in England that goes all the way back to Ovid, Socrates, and Seneca.

Understanding Deschamps's sense of the potential loss that accompanies translation practice and threatens the poet-translator's lasting fame finally allows us to understand fully why Deschamps engages, seemingly counter-intuitively, with Le Mote's defence of writing poetry in England. In positing a rich space of 'francophonie' in which there is no name 'n'en fable, n'en chançon qui n'ait servi en aucune contree' (lines $27 \mathrm{f}$.: 'neither in fable nor in song that might not have served in any region'), Le Mote opposes a dynamic vision of translation as gain to Vitry's vision of translation as inevitable loss. Vitry believes that the only 
logical conclusion of translation practice is the increasing distance of poetic forms from their originals until their eventual full degeneration into poetic puerility. But for Le Mote translation builds on existing forms and refashions them into new forms that can, in turn, be built upon and developed in any region where poets compose poetry. Le Mote's vision of poetic translation as offering the poet access to literary abundance, rather than sterility, offers Deschamps hope that his poetry will flourish in Chaucer's garden and, thus, in a francophone literary pantheon as beautiful plants worthy of further propagation elsewhere. If poetry serves equally well in any region, as Le Mote claims, then its movement across temporal, linguistic, and political, even war-torn, borders will be a fruitful dissemination, rather than a barren exile.

Deschamps's 'Ballade to Chaucer' suggests that translation in the medieval period was about far more than merely language, despite the evident centrality of cross-linguistic experimentation in multiple examples of translations from the period. Deschamps does note that Chaucer is translating into 'bon anglès', but, as we tease out the poem's multiple intertexts, the linguistic aspect fades into the background against the other claims being made concerning Chaucer's poetry. That Deschamps's emphasis on the use of classical allusion as a key criterion in evaluating Anglo-French literary exchange is also shared by Vitry and Le Mote, one generation earlier, raises the question of whether we might be seeing here smaller elements of a much larger and broader late medieval discourse surrounding Anglo-French translation within the formes fixes, in which the poet's literary relationship to classical antiquity occupied a vital political and cultural role. If so, then the heavy use of exempla from classical antiquity in Gower's Traitié, composed in formes fixes, which Gower opens and closes by emphasizing his choice to write in French as an Englishman, and Chaucer's Book of the Duchess and the Prologue to The Legend of Good Women, that also demonstrate a heavy engagement with both classical and contemporary French literary sources and the workings of translation, might be productively read as part of this larger cross-Channel discourse. By exploring what else, besides language, gets translated in cross-Channel literary exchange, what tropes, phrases, specific images, and intertextual literary references, we will be able to shine a brighter light on the politico-cultural, aesthetic, and ethical questions debated by cross-Channel poets in the late medieval period, especially in the context of the ongoing and destructive Hundred Years War.

Marquette University

ELIZAVETA STRAKHOV 


\section{NOTES}

My profound gratitude to David Wallace, Rita Copeland, Kevin Brownlee, and Medium Evum's reader for their thoughtful and illuminating comments over the long course of this piece's development.

${ }^{1}$ For the best text, see Ardis Butterfield, The Familiar Enemy: Chaucer, Language, and Nation in the Hundred Years War (Oxford, 2009), pp. I44-7; all translations from French are my own, though I have consulted Butterfield's.

2 William Calin, 'Deschamps' "Ballade to Chaucer" again, or the dangers of intertextual medieval comparatism', in Eustache Deschamps, French Courtier-Poet: His Work and his World, ed. Deborah M. Sinnreich-Levi (New York, 1998), pp. 73-83. For positive readings of the ballade, see T. Atkinson Jenkins, 'Deschamps's Ballade to Chaucer', Modern Language Notes, 33/5 (May 1918), 268-78; David Lampe, 'The courtly rhetoric of Chaucer's advisory poetry', Reading Medieval Studies, 9 (1983), 70-83; John Stevens, 'The "music" of the lyric: Machaut, Deschamps, Chaucer', in Medieval and Pseudo-medieval Literature: The J. A. W Bennett Memorial Lectures, Perugia, 1982-1983, ed. Piero Boitani and Anna Torti (Tübingen, 1984), pp. I09-29 (pp. I2If.); and Murray L. Brown, 'The Order of the Passion of Jesus Christ: a reconsideration of Eustache Deschamps' "Ballade to Chaucer", Mediaevalia, II (1989), 219-44, repr. as 'Poets, peace, the Passion, and the prince: Eustache Deschamps' "Ballade to Chaucer", in Chaucer's French Contemporaries: The Poetry/Poetics of Self and Tradition, ed. R. Barton Palmer (New York, 1999), pp. 187-215. See also Stephanie Downes, 'After Deschamps: Chaucer's French fame', in Chaucer and Fame: Reputation and Reception, ed. Isabel Davis and Catherine Nall (Cambridge, 2015), pp. 127-42.

3 Eustache Deschamps, Euvres complètes, ed. Auguste-H. E. Queux de St.-Hilaire and Gaston Raynaud, Sociéte des anciens textes français, II vols (Paris, I878-1903) (hereafter Euvres), II, 33f. (no. 2II) and I, Io6f. (no. 26). On Deschamps's proto-nationalism, see, in particular, Gaston Duchet-Suchaux, 'Émergence d'un sentiment national chez Eustache Deschamps', in Autour d'Eustache Deschamps: Actes du Colloque du Centre d'Études Médiévales de l'Université de Picardie-Jules Verne, Amiens, 5-8 Novembre, I998, ed. Danielle Buschinger (Amiens, 1999), pp. 73-7; Liliane Dulac, 'La Représentation de la France chez Eustache Deschamps et Christine de Pizan', in Autour, pp. 79-92; Earl Jeffrey Richards, 'The uncertainty of defining France as a nation in the works of Eustache Deschamps', in Inscribing the Hundred Years' War in French and English Cultures, ed. Denise N. Baker (New York, 2000), pp. 159-76; and Butterfield, Familiar, pp. 130-43.

${ }^{4}$ Deschamps, Euvres, V, 79f. (no. 893); on this lyric, see David Wallace, Premodern Places: From Calais to Surinam, Chaucer to Aphra Behn (Oxford, 2006), pp. 54-6, and Butterfield, Familiar, pp. I4I-3.

5 Butterfield, Familiar, pp. $236 \mathrm{f}$.

6 John M. Bowers, 'Chaucer after Retters: the wartime origins of English literature', in Inscribing, pp. 9I-I25 (p. IOO).

7 Jacques Kooijman suggests between 1377 and I380 in 'Envoi des fleurs: à propos des échanges littéraires entre la France et l'Angleterre sous la Guerre de Cent Ans', in Études de langue et de littérature françaises offertes à André Lanly, ed. Bernard Guidoux (Nancy, 1980), pp. 173-83 (p. 181); Wimsatt posits the late 1380s in Chaucer and his French Contemporaries: Natural Music in the Fourteenth Century (Toronto, 199I), p. 248; Murray 
L. Brown holds to I39I in 'Poets, peace', though his argument relies heavily on conjecture; and I. S. Laurie proposes either 1384 or 1396 in 'Eustache Deschamps: $1340($ ?)-1404', in Eustache Deschamps, pp. I-39 (pp. I5f. and n. 77).

8 Butterfield's Familiar, for example, features 'Language' in the very title of her book; consider also the prominence assumed by questions of linguistic difference and exchange in Language and Culture in Medieval Britain: The French of England c.II00-I500, ed. Jocelyn Wogan-Browne et al. (York, 2009).

9 See Butterfield, Familiar, pp. 144-7, for a discussion of the meaning of 'pandras' in this line.

10 The syntax is somewhat thorny, so I offer a loose translation of what seems to be the main sense to me here. Cf. the same origin story for 'England' from 'Angela' in another of Deschamps's ballades: Euvres, VI, 87f. (no. II54). The notion of the name 'England' deriving from a Saxon queen, or princess, named Angela occurs in Bartholomaeus Anglicus' De proprietatibus rerum and Ranulf Higden's Polychronicon: see Lesley Johnson, 'Return to Albion', Arthurian Literature, I3 (1995), 19-40 (pp. 24f. n. 13) and, on the transmission of this origin story all the way up to Edmund Spenser's Faerie Queene, Carrie Anna Harper, The Sources of the British Chronicle History in Spenser's Faerie Queene (Ph. D. diss., Bryn Mawr College, I910), pp. 165-8.

11 The referent of 'eulx' appears unclear, and previous scholars have generally taken this phrase to be functioning contextually in a reflexive sense - to authorize themselves - a sense I agree with and am conveying with the more oblique 'to create authority'.

${ }^{12}$ See James Wimsatt, Chaucer and the French Love-Poets: The Literary Background of The Book of the Duchess (Chapel Hill, NC, I968), pp. I47-9 and Contemporaries, pp. 48-58; Mary Rouse and Richard Rouse, 'The goldsmith and the peacocks: Jean de le Mote in the household of Simon de Lille, I340', Viator, 28 (I997), 28I-305, and Janet van Der Meulen, 'Simon de Lille et sa commande du Parfait du paon: pour en finir avec le Roman de Perceforest', in Patrons, Authors and Workshops: Book Production in Paris around I40o, ed. Godried Croenen and Peter Ainsworth (Louvain, 2006), pp. 223-38.

13 Philippe de Vitry, clerk, canon, and eventually Bishop of Meaux, worked in various administrative capacities for Philip VI and Jean II and was hailed by his contemporaries and immediate successors as the pre-eminent poet and composer of courtly love poetry and music of his day, though little of his auvre remains extant. On his life, see A. Coville, 'Philippe de Vitri: notes biographiques', Romania, 59 (1933), 520-47, and Margaret Bent and Andrew Wathey, 'Vitry, Philippe de', Grove Music Online, Oxford Music Online, <http://proxy.library.upenn.edu:4087/subscriber/article/grove/music/29535> (accessed I3 September 2013). On his extant works, see Leo Schrade, 'Philippe de Vitry: some new discoveries', Musical Quarterly, 42/3 (July 1956), 330-54; Ernest H. Sanders, 'The early motets of Philippe de Vitry', Journal of the American Musicological Society, 28/I (Spring 1975), 24-45; Sarah Fuller, 'A phantom treatise of the fourteenth century? The Ars nova', The Journal of Musicology, 4/I (Winter 1985-6), 23-50; and Daniel Leech-Wilkinson, 'The emergence of Ars nova', Journal of Musicology, I3/3 (Summer 1995), 285-317.

${ }^{14}$ F. N. M. Diekstra suggests in 'The poetic exchange between Philippe de Vitry and Jean de le Mote: a new edition', Neophilologus, 70/4 (1986), 504-19 that 'Antheus' is an orthographic variant of 'Antheon', itself a known orthographic variant for Actaeon; see Roman de Thèbes, lines 9127f.: 'Antheon ... Qui apres fu en cerf muez' ('Antheon ... who 
was afterwards transformed into a stag'); Christine de Pizan, Livre de mutacion de fortune, lines 4847-9: 'A Antheon l'ont bien monstré / Qui par ses propres chiens oultré / Y fu, si tost com cerfs devint ...' ('It was made apparent to Antheon, who was destroyed by his own dogs as soon as he became a stag'); and Deschamps's ballade no. 90I in Euvres, V, 9If.: '... Antheus, en la fourest doubteuse, / Quant cerfs devint ...' ('Antheus, in the dangerous forest, when he became a stag'). However, 'Antheus' as a name for the giant Antaeus, vanquished by Hercules, is found in Jean de Meun's translation of Boethius' Consolatio and Nicolas Trevet's commentary on the Consolatio (see Chaucer's Boece and the Medieval Tradition of Boethius, ed. A. J. Minnis, Chaucer Studies, I8 (Woodbridge, 1993), p. I52); Dante, De monarchia (II. 7. IO); as well as Chaucer, Boece (IV. m. 7) and Monk's Tale (line 2108). Both readings are equally plausible: to call Le Mote an Actaeon (Diekstra's reading) would imply that Le Mote has trespassed into the private, sacred space of poetry and must therefore save himself in flight. To call him an Antaeus implies that, following the myth, Le Mote's departure from the Continent to England has removed him from his parental ground, i.e. the Continent, from which he gathers (poetic) strength, and he is now weakened on foreign soil. Given the complexity inherent in the whole work, it is possible that Vitry was aware of and playing with both potential readings.

15 Texts from Diekstra, 'Exchange'. The exchange is extant in two manuscripts: a large anthology of fourteenth-century lyric, Philadelphia, University of Pennsylvania, Codex 902 (fols $23^{\mathrm{r}-\mathrm{v}}$ ), and a wide-ranging, multilingual miscellany, Paris, Bibliothèque nationale de France, fonds latin 3343 (fols $\mathrm{IIO}^{\mathrm{r}-\mathrm{v}}$ ). See also Earnest Pognon, 'Ballades mythologiques de Jean De Le Mote, Philippe de Vitri, Jean Campion', Humanisme et Renaissance, 5/3 (I938), 385-4I7 and, for discussion of the exchange's classical allusions in the context of other contemporary poetry, Nicola F. McDonald, 'Doubts about Medea, Briseyda and Helen: interpreting classical allusion in the fourteenth-century French ballade Medee fu en amer veritable', in Studies in English Language and Literature: 'Doubt wisely', Papers in Honor of E. G. Stanley, ed. M. J. Toswell and E. M. Tyler (New York, 1996), pp. 252-66. 16 To make someone a 'Hugo' is a reference to a well-known motet by Vitry, Cum statua / Hugo, in which Vitry denounces someone named Hugo, exact identity unknown, in exceedingly harsh terms. Le Mote is not alone in alluding to this motet: a Latin poem narrating the exile of 'Hugo', with explicit allusions to Vitry's work, occurs in a midfifteenth-century humanist manuscript produced in Bohemia, which suggests 'being a Hugo' may have turned into some kind of commonplace; see Andrew Wathey, 'The motets of Philippe de Vitry and the fourteenth-century Renaissance', Early Music History, I2 (1993), II9-50 (p. I42 n. 5I) and Anna Zayaruznaya, The Monstrous New Art: Divided Forms in the Late Medieval Motet (Cambridge, 2015), p. Io6.

17 Text from Diekstra, 'Exchange', p. 509, notes on pp. 514-18.

18 Wimsatt, Contemporaries, p. 65 and Chaucer and the Poems of 'Ch' (Kalamazoo, Mich., 2009), p. 74 n. 3I.

19 Deschamps, Euvres, I, Io6f. (no. 26).

${ }^{20}$ It is unclear why Vitry, Le Mote, and Deschamps all adduce 'Gaul' to be a Greek word. Diekstra suggests a possible connection to Isidore's Etymologies, in which Isidore notes that the Gauls are said to derive their name from the Greek word for milk. The same derivation occurs in Bartolomaeus Anglicus' De proprietatibus rerum and Higden's Polychronicon: see Diekstra, 'Exchange', p. 5II n. I. 
${ }^{21}$ Deschamps, Euvres, I, 25If. (no. I24).

22 Butterfield, Familiar, p. 237.

${ }^{23}$ See Debra Hassig, 'Sex in the bestiaries', in The Mark of the Beast: The Medieval Bestiary in Art, Life and Literature, ed. Debra Hassig and Debra Higgs Strickland (New York, I999), pp. 77 f. and associated bibliography.

${ }^{24}$ Wimsatt, Chaucer, p. 69. Vitry was a close friend of Petrarch, which may account for his knowledge of other Italian literature: see Coville, 'Philippe' and Bent and Wathey, 'Vitry'. See further Andrew Wathey, 'Philippe de Vitry's books', in Books and Collectors I200-I650: Essays Presented to A. G. Watson, ed. J. Carley and C. Tite (London, 1997), pp. I45-52 and 'Myth and mythography in the motets of Philippe de Vitry', Musica e storia, 6/I (I998), 8I-I06.

${ }^{25}$ Diekstra, 'Exchange', p. 514.

${ }^{26}$ Le Mote was also paid for providing the king with entertainment in Eltham, one of the royal residences, in I343: see Nigel Wilkins, 'Music and poetry at court: England and France in the late Middle Ages', in Words and Music in Medieval Europe (Farnham, 20II), p. I92, citing royal household account records.

${ }^{27}$ Nigel Wilkins, 'En regardant vers le païs de France: the ballade and the rondeau, a cross-Channel history', in Words and Music, pp. $299 \mathrm{f}$.

${ }^{28}$ Gilles le Muisis, Poésies, ed. Kervyn de Letterhove (Louvain, I882), I, 89.

29 See Jonathan Sumption, The Hundred Years War, II: Trial by Fire (Philadelphia, Pa, 1999), pp. 195-249, 35I-454.

${ }^{30}$ Vitry's periphrase 'fountain of Cirrha' as a synonym for 'Hippocrene' is traceable to a mid-eleventh-century encyclopedic compendium, Papias Grammaticus' Elementarium, where Cirrha is glossed as one of the two peaks found on Mount Parnassus, instead of its more common identification in classical works such as Statius' Thebaid, Pausanias' Description of Greece, and Claudian's Gigantomachy as a port in Delphi, in the same region as, but not actually on Parnassus. On Vitry's ownership of a manuscript of the Elementarium, see Wathey, 'Myth', p. 87. Papias is most likely getting his information from Isidore, who also gives Cirrha and Nysa as the names for the two peaks in his Etymologies: see under Paradiso, I.I6: La Divina Commedia, ed. Umberto Bosco and Giovanni Reggio (Florence, 1979), Dartmouth Dante Project Online <dante.dartmouth.edu> (accessed 28 November 2015).

31 Text from Pognon, 'Ballades', p. 408. I have supplied a guess in brackets to clarify what looks like a corrupted line.

${ }^{32}$ See Wimsatt, Contemporaries, pp. 72f. The name Yde might be referring to the protagonist of Yde et Olive, an obscure Old French romance retelling the story of Iphis from Ovid's Metamorphoses; the other names are similarly occasionally decipherable as indicating minor characters from Graeco-Roman mythology.

33 Cf. Pognon, 'Ballades', pp. 395 f.

${ }^{34}$ In Ovid's Metamorphoses (V.37I-82), Pegasus creates the fountain of Hippocrene by stomping his hoof.

35 Le Mote might also be aware of the emergent metonymic use of the term as country, region, or territory that is already attested in Brisebarre de Douai's Li Restor du paon (I338), lines 357,788 , the second text in the aforementioned Paon cycle, to which Le Mote himself added the third and last instalment, Le Parfait du paon (I340). Richards discusses the changing conception of 'nation' in 'Uncertainty'. 
36 Euvres, I, 244f. (no. I24).

37 André Crepin, 'Chaucer et Deschamps', in Autour, pp. 37-43 (p. 4I); see also passim Wimsatt, Contemporaries, pp. $252 \mathrm{f}$.

38 There is, I believe, a clever wordplay in this line on the expression 'chapeau de sauz', or literally wreath of the willow tree, used as an image of mourning, cf., e.g., Gower's Mirour de l'omme, line 6.

39 Text from Deschamps, Euvres, V, 229f. (no. 984).

${ }^{40}$ On Deschamps's treatment and definition of 'rhetorique' in the address to Chaucer and other works, see Laura Kendrick, 'Rhetoric and the rise of public poetry: the career of Eustache Deschamps', Studies in Philology, 80/I (Winter 1983), I-I3.

${ }^{41}$ Morel is the surname with which Deschamps appears to have been born: Christine de Pizan's address to him, for example, is titled by her L'Epistre a Eustace Morel rather than 'Deschamps'. By contrast, 'Des champs' (literally, 'of the fields') is the name by which the poet called his home estate; after it was burned down by the English in a spate of wartime pillaging, Deschamps announced in a ballade that he would hereafter go by the name 'Brulé des Champs' ('Scorched of the Fields') in memory of his ruined home, a pseudonym he went on to use in a series of subsequent lyrics: Deschamps, Euvres, V, 5-7 (no. 835 and 836), 45f. (no. 866); VI, I68f. (no. II90); see also II, 86f. (no. 250). See further Laurie, 'Deschamps', If., David Wallace, Premodern, 49f., and Butterfield, Familiar, I36f. 42 See David Wallace, Chaucer and the Early Writings of Boccaccio (Woodbridge, 1985), pp. 50-3, and Chaucerian Polity: Absolutist Lineages and Associational Forms in England and Italy (Stanford, Calif., 1997), pp. 80-2.

${ }^{43}$ In a further layer of allusion, Jean de Meun's self-naming is itself an elegantly veiled intertextual reference to Ovid's Amores where Ovid laments the death of Tibullus, whom he portrays as joining Catullus and Gallus in Elysium (3.9.59-68).

${ }^{44} \mathrm{I}$ am grateful to Kevin Brownlee for drawing my attention to this. It is also interesting to note this possible juxtaposition of Geoffrey Chaucer with Geoffrey of Monmouth in the context of the debate over whether 'Englyssh Gaufride' in Chaucer's House of Fame (3.1470) refers to Chaucer himself, to Geoffrey of Monmouth, or both: see, in particular, Helen Cooper, 'The Four Last Things in Dante and Chaucer: Ugolino in the House of Rumour', New Medieval Literatures, 3 (1999), pp. 39-66 (pp. 58-60), who further points out that 'English Gaufride' also comes sixth of six in that passage within a list of authors writing on Troy.

${ }^{45}$ Margaret Bent, 'Polyphony of texts and music in the fourteenth-century motet: Tribum que non abhorruit / Quoniam secta latronum / Merito hec patimur and its "quotations", in Hearing the Motet: Essays on the Motet of the Middle Ages and Renaissance, ed. Dolores Pesce (Oxford, 1997), pp. 82-103.

46 On 'Antheus' as Actaeon, see n. I4 above. Incidentally, in one of his most explicitly anti-English lyrics, Deschamps, having again described the burning of his estate by English soldiers in the Hundred Years War, asks of his addressee: 'Comme jadiz fu mué Antheus, / Muez mon nom ...' (lines 27f., emphasis added: 'As Antheus was transformed once, transform my name ...'): Euvres, V, I7f. (no. 845). It seems clear, from the context, that Deschamps understands 'Antheus' as Actaeon, perhaps further suggested to him by the highly popular medieval legend of St Eustace, whose conversion to Christianity is spurred by seeing a stag with a cross between its antlers. Furthermore, Deschamps's lyric suggests 
that he connects the concept of Antheus/Actaeon with matters relating to the Hundred Years War, a link that points back to Vitry's address to Le Mote.

${ }^{47}$ Text from Ovid, Tristia, Ex Ponto, ed. G. P. Gould, trans. Arthur Leslie Wheeler (Cambridge, Mass., 1988). Aonia is another name for Boeotia, the region in which Mount Helicon is found; in the Metamorphoses, Ovid refers to the Muses on Helicon as 'Aonides' ('of Aonia') within the very same episode that relates Pegasus' miraculous production of Hippocrene, the fountain on Helicon (V.333). 